\title{
Arsenic speciation in saliva of acute promyelocytic leukemia patients undergoing arsenic trioxide treatment
}

\author{
Baowei Chen - Fenglin Cao • Chungang Yuan • \\ Xiufen Lu • Shengwen Shen • Jin Zhou $\cdot$ X. Chris Le
}

Received: 19 October 2012 /Revised: 21 December 2012 / Accepted: 22 December 2012 /Published online: 15 January 2013

(C) The Author(s) 2013. This article is published with open access at Springerlink.com

\begin{abstract}
Arsenic trioxide has been successfully used as a therapeutic in the treatment of acute promyelocytic leukemia (APL). Detailed monitoring of the therapeutic arsenic and its metabolites in various accessible specimens of APL patients can contribute to improving treatment efficacy and minimizing arsenic-induced side effects. This article focuses on the determination of arsenic species in saliva samples from APL patients undergoing arsenic treatment. Saliva samples were collected from nine APL patients over three consecutive days. The patients received $10 \mathrm{mg}$ arsenic trioxide each day via intravenous infusion. The saliva samples were analyzed using high-performance liquid chromatography coupled with inductively coupled plasma mass spectrometry. Monomethylarsonous acid and monomethylmonothioarsonic acid were identified along with arsenite, dimethylarsinic acid, monomethylarsonic acid, and arsenate. Arsenite was the predominant arsenic species, accounting for $71.8 \%$ of total arsenic in the saliva. Following the arsenic infusion each day, the percentage of methylated arsenicals significantly decreased, possibly suggesting that the arsenic methylation process was saturated by
\end{abstract}

B. Chen and F. Cao contributed equally to this paper.

Published in the topical collection Metallomics with guest editors Uwe Karst and Michael Sperling.

B. Chen $\cdot$ X. Lu $\cdot$ S. Shen $\cdot$ X. C. Le $(\bowtie)$

Analytical and Environmental Toxicology, Department of Laboratory Medicine and Pathology, University of Alberta, Edmonton, AB T6G 2G3, Canada

e-mail: xc.le@ualberta.ca

F. Cao $\cdot$ J. Zhou $(\bowtie)$

Department of Hematology, Harbin Medical University,

Harbin, China

e-mail: jinzhou85@163.com

C. Yuan

School of Environmental Sciences and Engineering, North China

Electric Power University, Baoding 071003 Hebei, China the high doses immediately after the arsenic infusion. The temporal profiles of arsenic species in saliva following each arsenic infusion over 3 days have provided information on arsenic exposure, metabolism, and excretion. These results suggest that saliva can be used as an appropriate clinical biomarker for monitoring arsenic species in APL patients.

Keywords Acute promyelocytic leukemia $\cdot$ Arsenic speciation $\cdot$ Saliva $\cdot$ Metabolism $\cdot$ Arsenic trioxide treatment

\section{Introduction}

Acute promyelocytic leukemia (APL) is a distinctive subtype of acute myelocytic leukemia characterized by reciprocal translocations between chromosomes 15 and 17. Many clinical trials have demonstrated that both new and relapsed APL patients can achieve complete remission after arsenic trioxide treatment [1-7]. Generally, APL patients receive intravenous infusions of an aqueous solution of inorganic arsenic over the course of $2-5 \mathrm{~h}[1,2,4,7]$. In spite of the good efficacy of arsenic treatment, fatalities of APL patients and arsenicinduced side effects, e.g., skin and gastrointestinal reactions, liver and cardiac dysfunction, and neuropathy, have also been reported [2, 4, 7-9]. With the aim of alleviating side effects and maximizing treatment efficacy, extensive efforts have been made to elucidate the mechanisms of action, such as the effects of arsenic on apoptosis, differentiation, degradation of oncogenic fusion proteins, and signal transduction [10-14], as well as metabolism of arsenic in APL patients [15-17].

Inorganic arsenic can be readily transformed in many organisms through a biological process consisting of alternating reduction and oxidative methylation reactions, which consequently leads to the formation of various arsenic metabolites $[15,18-22]$. Monomethylarsonic acid $\left(\mathrm{MMA}^{\mathrm{V}}\right)$ and dimethylarsinic acid $\left(\mathrm{DMA}^{\mathrm{V}}\right)$ have commonly been detected in human 
urine, saliva, and blood $[15,16,20-26]$. However, monomethylarsonous acid $\left(\mathrm{MMA}^{\mathrm{III}}\right)$ and dimethylarsinous acid $\left(\mathrm{DMA}^{\mathrm{III}}\right)$, which are proposed as important intermediates in the transformation process of inorganic arsenic, have been detected only in human urine [15, 27-29]. Recently, thiolated methylated arsenicals have also been identified as metabolites of inorganic arsenic in human urine [30,31].

Various arsenic metabolites exhibit differing toxicities. For instance, trivalent methylated arsenicals are more toxic than their pentavalent counterparts [12, 32-35], and the toxicities of thiolated arsenicals are greater than those of pentavalent oxygen-containing analogs [30, 36-38]. Owing to the extreme variations in the toxicity of arsenic metabolites, it is necessary to identify and quantify arsenic species in APL patients undergoing arsenic treatment. The speciation information will contribute to improve our understanding of arsenic metabolism and to the design of timely clinical intervention and personalized therapy.

Although previous studies have determined arsenicals in the urine and blood of APL patients undergoing arsenic treatment [15-17], arsenic speciation in the saliva of APL patients has not been reported. Salivary glands have high blood flows, and arsenic species in the blood could be distributed to saliva. Collection of saliva samples is noninvasive and readily achievable. Thus, determination of arsenic species in saliva can complement biomonitoring of arsenic species in urine and blood, serving as a potential biomarker for assessment of recent exposure. The primary objective of this work is to identify and quantify arsenic species in saliva samples from APL patients undergoing arsenic treatment. Achieving this objective involves the development of arsenic speciation analysis and the application of this technique to determining temporal profiles of arsenic species in saliva.

\section{Materials and methods}

\section{Reagents}

$\mathrm{MMA}^{\mathrm{III}}$ and $\mathrm{DMA}^{\mathrm{III}}$ were synthesized in the iodide form of $\mathrm{CH}_{3} \mathrm{AsI}_{2}$ and $\left(\mathrm{CH}_{3}\right)_{2} \mathrm{AsI}$ according to the literature [39], and were kept at 4 and $-20{ }^{\circ} \mathrm{C}$, respectively. Monomethylmonothioarsonic acid $\left(\mathrm{MMMTA}^{\mathrm{V}}\right)$ and dimethylmonothioarsinic acid $\left(\mathrm{DMMTA}^{\mathrm{V}}\right)$ were prepared according to a reported method [40], and were stored at $-20{ }^{\circ} \mathrm{C}$. Their stock solutions were freshly prepared in deionized water. Stock solutions of other standards $(1,000 \mathrm{mg} / \mathrm{L}$ as arsenic) were prepared by dissolving appropriate amounts of $\mathrm{As}^{\mathrm{III}}$, $\mathrm{As}^{\mathrm{V}}, \mathrm{DMA}^{\mathrm{V}}$ (all from Aldrich), and $\mathrm{MMA}^{\mathrm{V}}$ (Chem Service) in deionized water. Their working solutions were prepared daily by serial dilutions in deionized water.

Tetrabutylammonium hydroxide (Aldrich), malonic acid (Aldrich), and high-performance liquid chromatography
(HPLC) grade methanol (Fisher) were used for preparing the mobile phase. The mobile phase was filtered through a $0.45-\mu \mathrm{m}$ membrane filter.

A certified reference material ("Toxic Metals in FreezeDried Human Urine," certified reference material no. 18 from the National Institute for Environmental Studies, Japan Environment Agency) was used for quality control purposes. This certified reference material was reconstituted by dissolving it in $20.0 \mathrm{~mL}$ deionized water according to the instructions provided by the supplier. The certified value for $\mathrm{DMA}^{\mathrm{V}}$ was $36 \pm 9 \mu \mathrm{g} / \mathrm{L}$.

APL patients and sample collection

Saliva samples were collected from nine patients who were undergoing arsenic treatment at Harbin Medical University Hospital. Informed consent was acquired from each patient prior to the study, which was conducted in compliance with the guidelines and regulations of the ethical review boards of the University of Alberta and Harbin Medical University Hospital (200816). Demographic information on the APL patients is given in Table 1. Two relapsed patients were returning for arsenic treatment, and the other patients were newly diagnosed with APL. Before the start of sample collection, two patients (one returning and one new) did not receive arsenic treatment, whereas the other patients had been treated with arsenic for differing durations, as shown in Table 1.

Ten milligrams of $\mathrm{As}_{2} \mathrm{O}_{3}$ (Yida Pharmaceutical, Harbin, China) dissolved in a $10-\mathrm{mL}$ aqueous solution was added to $500 \mathrm{~mL}$ of $5 \%$ glucose normal saline solution for intravenous infusion. The infusion usually takes $2-4 \mathrm{~h}$. Arsenic was administered to patients 4,5 , and 9 over a period as long as $18 \mathrm{~h}$ because it caused them serious side effects. White blood cell counts and routine blood analysis were performed to monitor the health of APL patients. One saliva

Table 1 Demographic information on acute promyelocytic leukemia (APL) patients who participated in this study

\begin{tabular}{lllll}
\hline $\begin{array}{l}\text { Patient } \\
\text { ID }\end{array}$ & Gender & $\begin{array}{l}\text { Age } \\
\text { (years) }\end{array}$ & $\begin{array}{l}\text { New or } \\
\text { relapsed }\end{array}$ & $\begin{array}{l}\text { Duration of arsenic } \\
\text { treatment (days) }\end{array}$ \\
\hline 1 & F & 29 & Relapsed & 0 \\
2 & F & 36 & Relapsed & 4 \\
3 & F & 19 & New & 54 \\
4 & F & 24 & New & 0 \\
5 & F & 24 & New & 13 \\
6 & M & 30 & New & 11 \\
7 & F & 40 & New & 9 \\
8 & M & 50 & New & 44 \\
9 & F & 52 & New & 16 \\
\hline
\end{tabular}

$F$ female, $M$ male 
sample was collected from each patient immediately prior to daily infusion of arsenic. All patients then received intravenous infusions of the same dose of $\mathrm{As}^{\mathrm{III}}\left(10 \mathrm{mg} \mathrm{As} \mathrm{O}_{3}\right)$, and saliva samples were collected consecutively in the subsequent $24 \mathrm{~h}$ before the next infusion. Sample collection was repeated for two or three 24-h cycles following different $\mathrm{As}{ }^{\mathrm{III}}$ infusions. In total, 108 saliva samples were collected from nine APL patients. APL patients were required to rinse their mouths thoroughly with deionized water three times before saliva sampling; then they spat saliva samples directly into $15-\mathrm{mL}$ polyethylene centrifuge tubes. Immediately after sample collection, saliva samples were divided into three $1-\mathrm{mL}$ aliquots in $1.5-\mathrm{mL}$ vials. The vials were sealed with Parafilm and transported on dry ice. The samples were stored at $-20{ }^{\circ} \mathrm{C}$ until arsenic speciation analysis.

Pretreatment of saliva for arsenic speciation analysis

The method of pretreatment of saliva for arsenic speciation analysis has been described in the literature [23]. In brief, frozen saliva samples were thawed at room temperature and thoroughly vortex-mixed. A $0.5-\mathrm{mL}$ aliquot of saliva samples was diluted three times with deionized water in a 15$\mathrm{mL}$ centrifuge tube, and thoroughly vortex-mixed again. The diluted saliva samples were sonicated for $30 \mathrm{~min}$, and then filtered through a $0.45-\mu \mathrm{m}$ membrane filter prior to arsenic speciation analysis.

Identification and quantification of arsenic species by HPLCinductively coupled plasma mass spectrometry

An Agilent 1100 series HPLC system consisting of a pump, degasser, autosampler, column temperature control, and reversed-phase $\mathrm{C}_{18}$ column (ODS-3, $150 \mathrm{~mm} \times 4.6 \mathrm{~mm}$, 3- $\mu \mathrm{m}$ particle size; Phenomenex, Torrance, CA, USA) was used for the separation of arsenicals. An octadecylsilane guard cartridge $(4 \mathrm{~mm} \times 3 \mathrm{~mm})$ was mounted before the analytical column. The mobile phase consisted of $5 \mathrm{mM}$ tetrabutylammonium, $5 \%$ methanol, and $3 \mathrm{mM}$ malonic acid ( $\mathrm{pH}$ 5.65). The column was equilibrated with the mobile phase for at least $0.5 \mathrm{~h}$ at a flow rate of $0.8 \mathrm{~mL} / \mathrm{min}$ before sample injection. A $50-\mu \mathrm{L}$ aliquot of pretreated saliva samples was injected and separation was performed at a flow rate of $1.2 \mathrm{~mL} / \mathrm{min}$; the column temperature was maintained at $50{ }^{\circ} \mathrm{C}$.

The effluent from HPLC was introduced directly into the nebulizer of a 7500ce inductively coupled plasma (ICP) mass spectrometry (MS) instrument (Agilent Technologies, Japan) using PEEK tubing. The collision cell of the ICP MS instrument was operated in helium mode. Helium $(3.5 \mathrm{~mL} / \mathrm{min}$ ) was used in the octopole reaction cell to reduce isobaric and polyatomic interferences. The ICP operated at a radio-frequency power of $1,550 \mathrm{~W}$, and the flow rate of argon carrier gas was $0.9-1.0 \mathrm{~L} / \mathrm{min}$. Arsenic was monitored at $m / z$ 75. Chromatograms from HPLC separation were recorded by ICP-MS ChemStation (Agilent Technologies, Santa Clara, CA, USA).

Identification of MMMTA ${ }^{\mathrm{V}}$ by HPLC-electrospray ionization tandem mass spectrometry

For optimization of operating conditions, 1-5 $\mu \mathrm{M} \mathrm{MMMTA}^{\mathrm{V}}$ in a solution of methanol and water $(1: 1, \mathrm{v} / \mathrm{v})$ was infused into a triple-quadrupole mass spectrometer (5000 QTRAP, MDS SCIEX, Concord, ON, Canada) equipped with an electrospray ion source. The electrospray ionization (ESI) tandem mass spectrometry (MS/MS) instrument was operated in negative ionization mode. The characteristic multiple reaction monitoring transitions of $\mathrm{MMMTA}^{\mathrm{V}}$ were 155/107, 155/121, and $155 / 137$. The optimal parameters were as follows: IonSpray voltage $-4,500 \mathrm{~V}$, interface temperature $200{ }^{\circ} \mathrm{C}$, curtain gas flow rate $10 \mathrm{~L} / \mathrm{min}$, and declustering potential $-75 \mathrm{~V}$. The collision energy and the cell exit potential were -34 and $-13 \mathrm{~V}$ for $155 / 107,-22$ and $-11 \mathrm{~V}$ for $155 / 121$, and -22 and $-11 \mathrm{~V}$ for $155 / 137$.

The ESI-MS/MS instrument was coupled with an 1100 series HPLC system (Agilent, Santa Clara, CA, USA) equipped with a quaternary pump, degasser, column temperature control, and temperature-controlled autosampler. An anion-exchange column (PRP-X100, $50 \mathrm{~mm} \times 4.6 \mathrm{~mm}$, $10 \mu \mathrm{m}$; Hamilton, Reno, NV, USA) was used for separation, with the mobile phase comprising $50 \%$ methanol and $5 \mathrm{mM}$ ammonium formate $(\mathrm{pH} 6)$ at a flow rate of $1 \mathrm{~mL} / \mathrm{min}$. The temperature of the autosampler was kept at $4{ }^{\circ} \mathrm{C}$, and the injection volume was $50 \mu \mathrm{L}$.

\section{Results}

Trivalent and thiolated monomethylated arsenicals, $\mathrm{MMA}^{\mathrm{III}}$ and MMMTA $^{\mathrm{V}}$

Separation of eight arsenicals-As ${ }^{\mathrm{II}}, \mathrm{MMA}^{\mathrm{III}}, \mathrm{DMA}^{\mathrm{V}}$, $\mathrm{MMA}^{\mathrm{V}}, \mathrm{As}^{\mathrm{V}}$, DMMTA ${ }^{\mathrm{V}}, \mathrm{DMA}^{\mathrm{III}}$, and MMMTA ${ }^{\mathrm{V}}$-was achieved using ion-pair chromatography, as shown in Fig. 1, chromatogram A. A typical chromatogram of saliva samples from APL patients undergoing arsenic treatment is shown in Fig. 1, chromatogram B. These results demonstrated that $\mathrm{As}^{\mathrm{III}}, \mathrm{MMA}^{\mathrm{III}}, \mathrm{DMA}^{\mathrm{V}}, \mathrm{MMA}^{\mathrm{V}}, \mathrm{As}^{\mathrm{V}}$, and MMMTA $^{\mathrm{V}}$ were detectable in the saliva of APL patients. The presence of $\mathrm{MMA}^{\mathrm{III}}$ and $\mathrm{MMMTA}^{\mathrm{V}}$ in human saliva has not been reported in previous studies.

To confirm the presence of MMA ${ }^{\mathrm{III}}$ and $\mathrm{MMMTA}^{\mathrm{V}}$ in the saliva of APL patients, we analyzed the saliva samples spiked with authentic standards of $\mathrm{MMA}^{\mathrm{III}}$ or MMMTA $\mathrm{V}$. Figure 2 shows a comparison of the chromatograms of the 

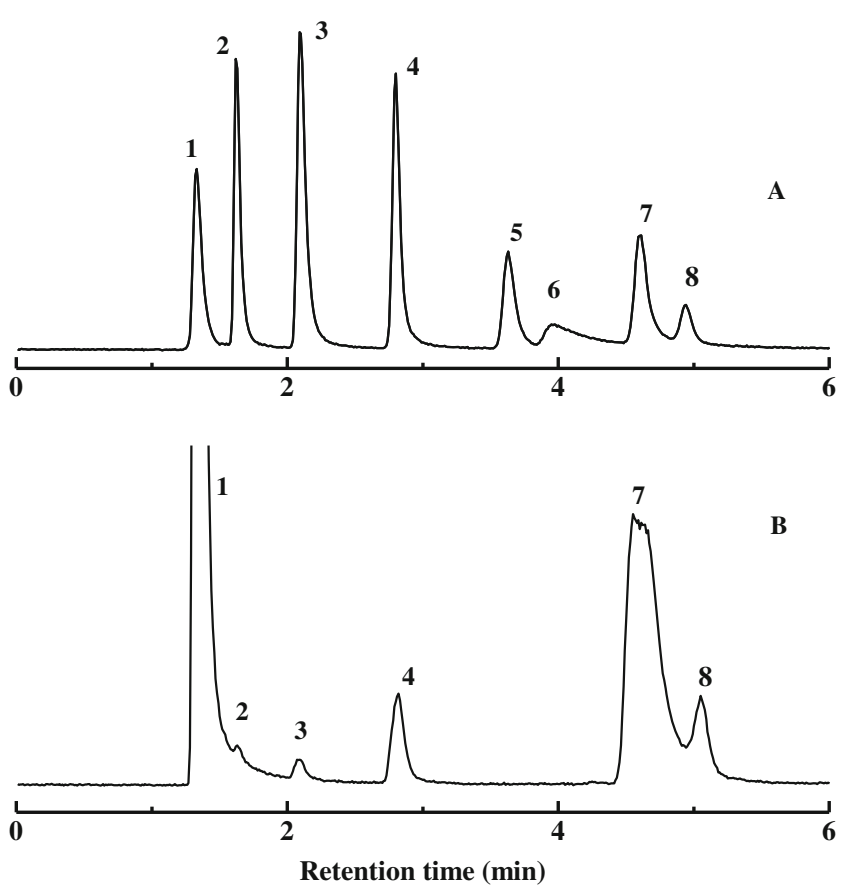

Fig. 1 Typical chromatograms of arsenic standards $(A)$ and saliva samples $(B)$ from acute promyelocytic leukemia (APL) patients. Separation was achieved using a reversed-phase ODS-3 column, and a mobile phase comprising $5 \mathrm{mM}$ tetrabutylammonium, $3 \mathrm{mM}$ malonic acid, and $5 \%$ methanol ( $\mathrm{pH}$ 5.65). Arsenic was detected at $\mathrm{m} / \mathrm{z} 75$ using an Agilent 7500ce inductively coupled plasma mass spectrometry (ICPMS) instrument with an octopole reaction system. Peaks 18 correspond to $\mathrm{As}^{\mathrm{III}}$, monomethylarsonous acid (MMA ${ }^{\mathrm{III}}$ ), dimethylarsinic acid $\left(\mathrm{DMA}^{\mathrm{V}}\right)$, monomethylarsonic acid $\left(\mathrm{MMA}^{\mathrm{V}}\right)$, dimethylmonothioarsonic acid, dimethylarsinous acid $\left(\mathrm{DMA}^{\mathrm{III}}\right), \mathrm{As}^{\mathrm{V}}$, and monomethylmonothioarsonic acid $\left(\mathrm{MMMTA}^{\mathrm{V}}\right)$, respectively

original sample and the same sample spiked with authentic standards. The spiked MMA ${ }^{\mathrm{III}}$ or MMMTA ${ }^{\mathrm{V}}$ standard was co-eluted with suspected compounds, giving rise to a distinct increase in the intensity of peak corresponding to MMA $^{\text {III }}$ or MMMTAV. The MMMTAV and MMA ${ }^{\mathrm{III}}$ standards are not stable. MMMTA ${ }^{\mathrm{V}}$ can decompose easily into $\mathrm{MMA}^{\mathrm{III}}$, and thereafter MMA ${ }^{\mathrm{III}}$ can be oxidized to MMA ${ }^{\mathrm{V}}$. Even when stored at $-80^{\circ} \mathrm{C}$ after synthesis, $\mathrm{MMMTA}^{\mathrm{V}}$ still can produce some $\mathrm{MMA}^{\mathrm{III}}$ and $\mathrm{MMA}^{\mathrm{V}}$ during the thawing process. Thus, spiking of MMMTA ${ }^{\mathrm{V}}$ also increased the intensities of the peaks of $\mathrm{MMA}^{\mathrm{III}}$ and $\mathrm{MMA}^{\mathrm{V}}$ (Fig. 2, chromatograms B). Because $\mathrm{MMA}^{\mathrm{III}}, \mathrm{MMA}^{\mathrm{V}}$, and MMMTA $^{\mathrm{V}}$ were well resolved in the chromatogram, these spiking experiments could still demonstrate the existence of MMA $^{\mathrm{III}}$ and MMMTA ${ }^{\mathrm{V}}$ in the saliva of APL patients. The chromatographic fraction containing $\mathrm{MMA}^{\mathrm{III}}$ was also collected and treated with hydrogen peroxide $\left(\mathrm{H}_{2} \mathrm{O}_{2}\right)$ to render the oxidation of $\mathrm{MMA}^{\mathrm{III}}$ to $\mathrm{MMA}^{\mathrm{V}}$. As demonstrated in Fig. 3, detection of $\mathrm{MMA}^{\mathrm{V}}$ in an $\mathrm{H}_{2} \mathrm{O}_{2}$-pretreated $\mathrm{MMA}^{\mathrm{III}}$ containing chromatographic fraction provided further evidence that $\mathrm{MMA}^{\mathrm{III}}$ was present in the saliva of APL patients.
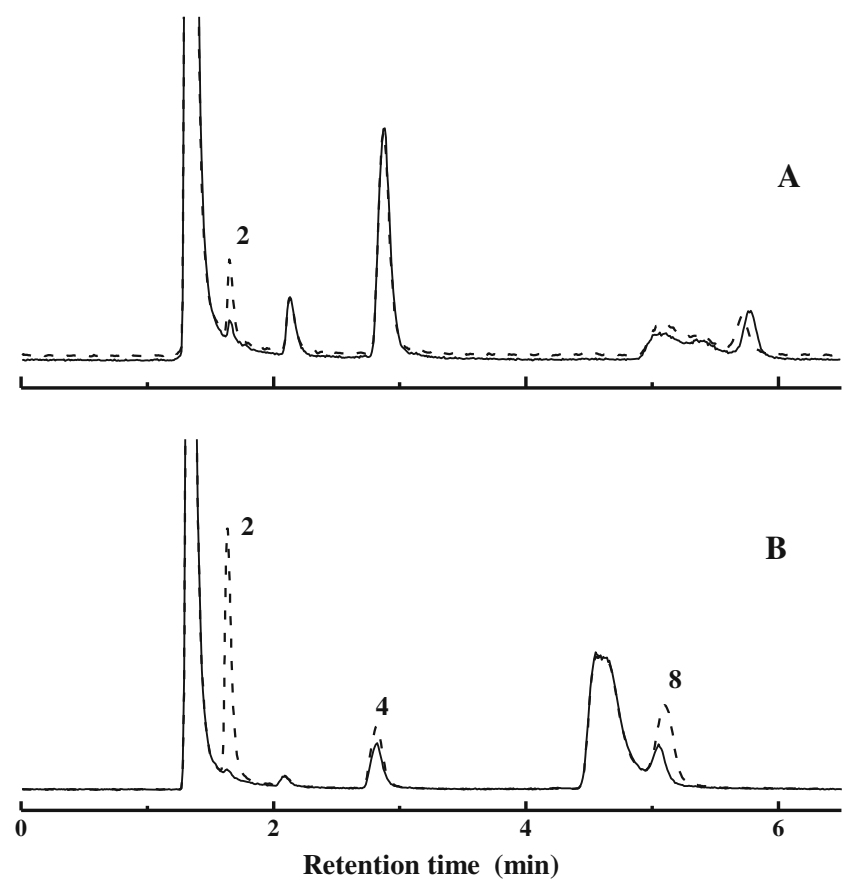

Fig. 2 Chromatograms of saliva samples and the same samples spiked with authentic arsenic standards. Peak identities and high-performance liquid chromatography (HPLC)-ICPMS conditions were the same as those for Fig. 1. A chromatograms were obtained from a saliva sample (solid trace) and the same sample spiked with authentic MMA ${ }^{\text {III }}$ (dashed trace). $B$ chromatograms were obtained from a saliva sample (solid trace) and the same sample spiked with $\mathrm{MMMTA}^{\mathrm{V}}$ (dashed trace)

ESI-MS/MS can provide information on the chemical structures of the compounds; therefore, an HPLC-ESIMS/MS method was developed for the identification of MMMTA $^{\mathrm{V}}$. Unfortunately, the concentration of MMMTA ${ }^{\mathrm{V}}$ in the saliva of APL patients was below the detection limit of ESI-MS/MS. Nevertheless, the authenticity of the synthesized MMMTA ${ }^{\mathrm{V}}$ standard used was confirmed using the ESI-MS/MS method. As shown in Fig. 4, the peaks representing characteristic ion transitions of MMMTA ${ }^{\mathrm{V}}(155 / 107$, $155 / 121$, and 155/137) were superimposed, which demonstrated the authenticity of the MMMTA ${ }^{\mathrm{V}}$ standard synthesized in our laboratory.

The results for $\mathrm{MMA}^{\mathrm{III}}$ and MMMTA ${ }^{\mathrm{V}}$ in the saliva of APL patients are summarized in Table 2. MMA ${ }^{\mathrm{III}}$ and MMMTA $^{\mathrm{V}}$ were detected in $49 \%$ and $22 \%$ of saliva samples from APL patients, respectively. The mean concentration of $\mathrm{MMA}^{\mathrm{III}}$ in all detectable saliva samples was $1.4 \mathrm{ng} / \mathrm{mL}$, and the mean concentration of MMMTA ${ }^{\mathrm{V}}$ was $3.6 \mathrm{ng} / \mathrm{mL} \mathrm{MMA}^{\mathrm{III}}$ and MMMTA ${ }^{\mathrm{V}}$ accounted for $2.2 \%$ and $4.0 \%$ of total arsenic in the saliva of APL patients, respectively. Table 3 shows the concentrations of $\mathrm{MMA}^{\mathrm{III}}$ and MMMTA $^{\mathrm{V}}$ in the saliva of each of the APL patients. $\mathrm{MMA}^{\mathrm{III}}$ was detected in saliva samples from each of the APL patients. However, MMMTA ${ }^{\mathrm{V}}$ was only found in the saliva of patients 3,7 , and 8 . The mean concentrations of 


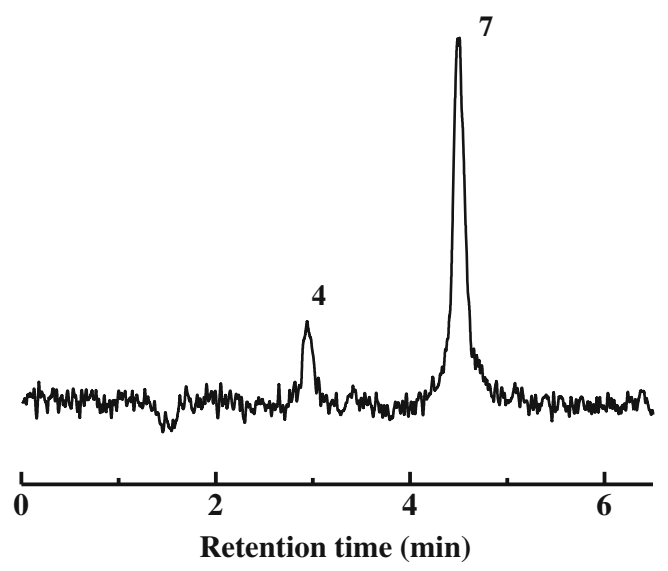

Fig. 3 A chromatogram obtained from HPLC-ICPMS analysis of an $\mathrm{H}_{2} \mathrm{O}_{2}$-treated chromatographic fraction containing MMA ${ }^{\mathrm{III}}$. Peak identities and HPLC-ICPMS conditions are the same as those for Fig. 1

$\mathrm{MMA}^{\mathrm{III}}$ and $\mathrm{MMMTA}^{\mathrm{V}}$ differed among the APL patients. The saliva of patient 8 contained the highest concentrations of $\mathrm{MMA}^{\mathrm{III}}(1.9 \pm 0.6 \mathrm{ng} / \mathrm{mL})$ and $\mathrm{MMMTA}^{\mathrm{V}}(5.3 \pm$ $2.9 \mathrm{ng} / \mathrm{mL}$ ) among all patients.

$\mathrm{As}^{\mathrm{III}}, \mathrm{DMA}^{\mathrm{V}}, \mathrm{MMA}^{\mathrm{V}}$, and $\mathrm{As}^{\mathrm{V}}$

The results for $\mathrm{As}^{\mathrm{III}}, \mathrm{DMA}^{\mathrm{V}}, \mathrm{MMA}^{\mathrm{V}}$, and $\mathrm{As}^{\mathrm{V}}$ in saliva samples from APL patients are also shown in Table 2. As ${ }^{\mathrm{III}}$, $\mathrm{DMA}^{\mathrm{V}}, \mathrm{MMA}^{\mathrm{V}}$, and $\mathrm{As}^{\mathrm{V}}$ were detectable in $98 \%$ of saliva samples. The mean concentration was $39.1 \mathrm{ng} / \mathrm{mL}$ for $\mathrm{As}^{\mathrm{III}}$,

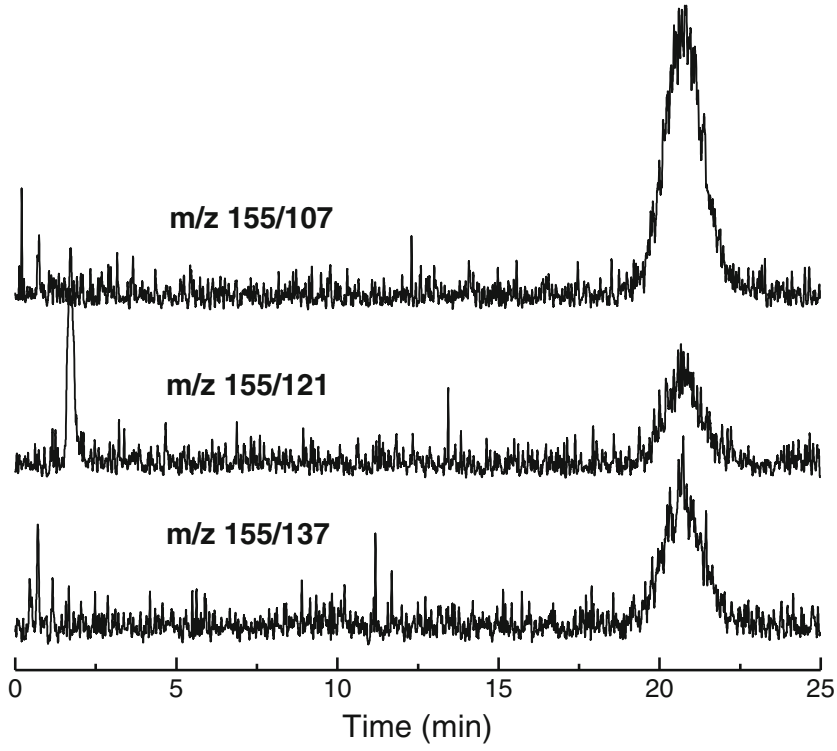

Fig. 4 Chromatogram obtained from HPLC-electrospray ionization tandem mass spectrometry (ESI-MS/MS) analysis of synthesized MMMTA $^{\mathrm{V}}$ standard. Anion-exchange separation was performed using a Hamilton PRP-X100 column and a mobile phase comprising $50 \%$ methanol and $5 \mathrm{mM}$ ammonium formate $(\mathrm{pH} 6)$. ESI-MS/MS was performed in multiple reaction monitoring mode. Three characteristic ion transitions, $155 / 107,155 / 121$, and $155 / 137$, of $\mathrm{MMMTA}^{\mathrm{V}}$ were monitored simultaneously
$9.2 \mathrm{ng} / \mathrm{mL}$ for $\mathrm{As}^{\mathrm{V}}, 1.0 \mathrm{ng} / \mathrm{mL}$ for $\mathrm{DMA}^{\mathrm{V}}$, and $2.0 \mathrm{ng} / \mathrm{mL}$ for MMA $^{\mathrm{V}}$. The summed concentration of all arsenicals in the saliva ranged from 0.1 to $210.1 \mathrm{ng} / \mathrm{mL}$, with a mean concentration of $52.2 \mathrm{ng} / \mathrm{mL}$. As ${ }^{\mathrm{III}}$ was the predominant species in the saliva of APL patients, and accounted for $71.8 \%$ of arsenic in the saliva.

The arsenic concentration was low in two saliva samples collected from patients 1 and 4 before the first arsenic injection (Table 3 ). The saliva of patient 1 contained only $0.3 \mathrm{ng} / \mathrm{mL} \mathrm{As}^{\mathrm{III}}$, and the saliva of patient 4 contained $0.1 \mathrm{ng} / \mathrm{mL} \mathrm{DMA}^{\mathrm{V}}$ and $0.1 \mathrm{ng} / \mathrm{mL} \mathrm{As}^{\mathrm{V}}$. The rest of the saliva samples were collected after the first infusion of arsenic, and the concentrations of arsenic were much higher than in the samples collected before any infusion of arsenic. As ${ }^{\mathrm{III}}$, $\mathrm{DMA}^{\mathrm{V}}, \mathrm{MMA}^{\mathrm{V}}$, and $\mathrm{As}^{\mathrm{V}}$ were detected in all saliva samples collected after the first infusion of arsenic, and $\mathrm{As}^{\mathrm{III}}$ was consistently the predominant arsenic species in the saliva of all patients. Although the same dose of arsenic trioxide was administered to all APL patients, the mean concentrations of arsenicals differed among individual APL patients. Patients $2,3,7$, and 8 had higher concentrations of arsenic in the saliva compared with the other patients.

\section{Temporal profiles of common arsenic species}

Figure 5 shows the temporal profiles of four common arsenic species $\left(\mathrm{As}^{\mathrm{III}}, \mathrm{DMA}^{\mathrm{V}}, \mathrm{MMA}^{\mathrm{V}}\right.$, and $\left.\mathrm{As}^{\mathrm{V}}\right)$ and their sum in the saliva of patients 4 and 6 . Before the study, patient 4 did not receive an arsenic injection, but arsenic was administered to patient 6 (relapsed) for 11 days. Saliva samples were consecutively collected for $72 \mathrm{~h}$ from patient 4 (Fig. 5a) and for $52 \mathrm{~h}$ from patient 6 (Fig. 5b). Three infusions of arsenic were administered to patient 4 during the sample collection period, and two infusions were administered to patient 6 . The interval between arsenic infusions was $24 \mathrm{~h}$. As shown in Fig. 5a, the arsenic concentration was low in the saliva sample of patient 4 before arsenic infusion. Following the first arsenic infusion, the concentrations of arsenicals in the saliva increased immediately, and decreased thereafter. The profiles were similar following the second and third infusions. Nevertheless, the overall level of arsenic in the saliva increased with the progression of arsenic treatment, indicating that arsenic had accumulated in the body of patient 4 . Compared with patient 4 , the background arsenic concentration in the first saliva sample of patient 6 (Fig. 5b) was higher because arsenic trioxide had been administered to this patient 11 times over 11 days prior to the study. The arsenic concentration in the saliva of patient 6 showed a delayed increase in response to arsenic infusion, and similar patterns of changes in the two subsequent monitoring cycles.

Temporal profiles of percentages of methylated arsenicals in the saliva of patients 4 and 6 are presented in Fig. 6 . 
Table 2 Summary of arsenic species in saliva samples collected from APL patients
$N D$ not detectable, $D M A^{V}$ dimethylarsinic acid, $M M A^{V}$ monomethylarsonic acid, $M M A^{I I I}$ monomethylarsonous acid, $M M M T A^{V}$ monomethylmonothioarsonic acid

\begin{tabular}{|c|c|c|c|c|c|c|}
\hline \multirow[t]{2}{*}{$\begin{array}{l}\text { Arsenic species } \\
\text { in saliva sample }\end{array}$} & \multirow[t]{2}{*}{$\begin{array}{l}\text { Mean concentration } \\
(\mathrm{ng} / \mathrm{mL})\end{array}$} & \multirow[t]{2}{*}{$\begin{array}{l}\text { Detectable } \\
\text { range }(\mathrm{ng} / \mathrm{mL})\end{array}$} & \multirow[t]{2}{*}{$\begin{array}{l}\text { Number of } \\
\text { detectable } \\
\text { samples }\end{array}$} & \multirow[t]{2}{*}{$\begin{array}{l}\text { Percentage of } \\
\text { detectable } \\
\text { samples }\end{array}$} & \multicolumn{2}{|c|}{$\begin{array}{l}\text { Percent concentration } \\
\text { over sum of all } \\
\text { species }\end{array}$} \\
\hline & & & & & Mean & Range \\
\hline $\mathrm{As}^{\mathrm{III}}$ & 39.1 & $0.3-181.5$ & 106 & 98 & 72.4 & $0-100$ \\
\hline $\mathrm{As}^{\mathrm{V}}$ & 9.2 & ND to 84.6 & 106 & 98 & 18.7 & $0-72.0$ \\
\hline $\mathrm{DMA}^{\mathrm{V}}$ & 1.0 & ND to 5.2 & 106 & 98 & 3.0 & $0-34.7$ \\
\hline $\mathrm{MMA}^{\mathrm{V}}$ & 2.0 & ND to 7.3 & 106 & 98 & 4.8 & $0-17.9$ \\
\hline $\mathrm{MMA}^{\mathrm{III}}$ & 1.4 & ND to 4.8 & 53 & 49 & 2.2 & $0-4.1$ \\
\hline MMMTA $^{\mathrm{V}}$ & 3.6 & ND to 10.6 & 24 & 22 & 4.0 & $0-9.2$ \\
\hline Sum of all species & 52.2 & $0.1-210.1$ & & & & \\
\hline
\end{tabular}

Following arsenic infusion, the percentages of $\mathrm{MMA}^{\mathrm{V}}$, $\mathrm{DMA}^{\mathrm{V}}$, and their sum decreased in the saliva of both patients, suggesting that the methylation efficiency of As ${ }^{\text {III }}$ was inhibited by accumulating As ${ }^{\mathrm{III}}$. However, there was a difference in the temporal profiles of the percentages of salivary arsenicals between patients 4 and 6 . The percentage of methylated arsenicals in the saliva of patient 4 declined continuously from $35 \%$ to $6 \%$, as shown in Fig. 6a. For patient 6 , the percentages of methylated arsenicals decreased immediately following arsenic infusion, and increased thereafter (Fig. 6b). A comparably similar profile between the two patients was repeated only after the second infusion.

\section{Discussion}

Following arsenic trioxide administration, a portion of As ${ }^{\mathrm{III}}$ can be transformed into methylated arsenicals in the body of APL patients through the processes of biological methylation
$[19,41]$. Salivary glands have high blood flow, and chemicals and their metabolites in blood can be distributed in saliva through passive diffusion, active transport, and ultrafiltration [42-45]. Our previous efforts showed that As ${ }^{\mathrm{III}}$ and its metabolites are present in saliva in populations who were chronically exposed to arsenic via drinking water or from chromated copper arsenate treated wood in playgrounds [23-25]. No attention has been paid to arsenic speciation in human saliva in clinical settings, in which APL patients were acutely exposed to high doses of $A s^{\mathrm{III}}$ via intravenous infusion.

Most arsenic in the saliva of APL patients was detected as $\mathrm{As}^{\mathrm{III}}$. $\mathrm{MMA}^{\mathrm{V}}$ and $\mathrm{DMA}^{\mathrm{V}}$, metabolites of $\mathrm{As}^{\mathrm{III}}$ commonly found in human urine $[15,16,20-26]$, were also detected in saliva of APL patients. As important intermediates in the transformation processes of $\mathrm{As}^{\mathrm{III}}$, $\mathrm{MMA}^{\mathrm{III}}$ and $\mathrm{DMA}^{\mathrm{III}}$ were found in human urine in previous studies [15, 27-29]. Our present study demonstrates the presence of $\mathrm{MMA}^{\mathrm{III}}$ in the saliva of APL patients who received a high dose of As ${ }^{\mathrm{III}}$, which provides additional evidence of biomethylation of

Table 3 Summary of arsenic species in saliva samples from individual APL patients

\begin{tabular}{|c|c|c|c|c|c|c|c|c|}
\hline \multirow{2}{*}{$\begin{array}{l}\text { Before or after the } \\
\text { first arsenic infusion }\end{array}$} & \multirow{2}{*}{$\begin{array}{l}\text { ID of APL } \\
\text { patient }\end{array}$} & \multirow{2}{*}{$\begin{array}{l}\text { Number of } \\
\text { samples }\end{array}$} & \multicolumn{6}{|c|}{ Concentrations of arsenic species $(\mathrm{ng} / \mathrm{mL})[$ mean $\pm \mathrm{SD}(n)]$} \\
\hline & & & $\mathrm{As}^{\mathrm{III}}$ & $\mathrm{DMA}^{\mathrm{V}}$ & $\mathrm{MMA}^{\mathrm{V}}$ & $\mathrm{As}^{\mathrm{V}}$ & $\mathrm{MMA}^{\mathrm{III}}$ & MMMTA $^{\mathrm{V}}$ \\
\hline \multirow[t]{2}{*}{ Before } & 1 & 1 & 0.3 & ND & ND & ND & ND & ND \\
\hline & 4 & 1 & ND & 0.1 & ND & 0.1 & ND & ND \\
\hline \multirow[t]{9}{*}{ After } & 1 & 18 & $12.1 \pm 9.0$ & $0.7 \pm 0.5$ & $1.3 \pm 0.9$ & $3.7 \pm 3.1$ & $0.6 \pm 0.2(2)$ & ND \\
\hline & 2 & 9 & $57.4 \pm 17.7$ & $1.3 \pm 0.5$ & $4.3 \pm 2.0$ & $5.1 \pm 1.8$ & $1.3 \pm 0.3(9)$ & ND \\
\hline & 3 & 7 & $59.1 \pm 23.2$ & $0.5 \pm 0.1$ & $2.3 \pm 0.6$ & $13.9 \pm 9.0$ & $1.6 \pm 0.5(4)$ & $2.9 \pm 1.6(7)$ \\
\hline & 4 & 9 & $20.1 \pm 25.1$ & $0.6 \pm 0.4$ & $0.9 \pm 0.6$ & $2.8 \pm 2.2$ & $0.7 \pm 0.6(6)$ & $\mathrm{ND}$ \\
\hline & 5 & 20 & $27.0 \pm 11.3$ & $0.7 \pm 0.3$ & $1.7 \pm 0.8$ & $13.8 \pm 9.8$ & $0.4 \pm 0.1$ & ND \\
\hline & 6 & 16 & $35.5 \pm 17.0$ & $1.8 \pm 1.0$ & $1.8 \pm 1.1$ & $3.2 \pm 2.5$ & $1.3 \pm 0.7$ (14) & ND \\
\hline & 7 & 6 & $96.9 \pm 46.3$ & $1.2 \pm 0.6$ & $1.4 \pm 0.7$ & $6.3 \pm 5.4$ & $2.7 \pm 1.5(4)$ & $1.0 \pm 0.5$ (5) \\
\hline & 8 & 11 & $64.7 \pm 20.1$ & $0.9 \pm 0.2$ & $2.9 \pm 1.2$ & $15.7 \pm 7.4$ & $1.9 \pm 0.6(10)$ & $5.3 \pm 2.9(11)$ \\
\hline & 9 & 10 & $45.2 \pm 18.9$ & $1.7 \pm 1.4$ & $2.1 \pm 1.3$ & $21.4 \pm 22.9$ & $0.8(1)$ & $1.6(1)$ \\
\hline
\end{tabular}

$N D$ not detectable, $S D$ standard deviation, $n$ number of samples in which $\mathrm{MMA}^{\mathrm{III}}$ and MMMTA ${ }^{\mathrm{V}}$ were detected 

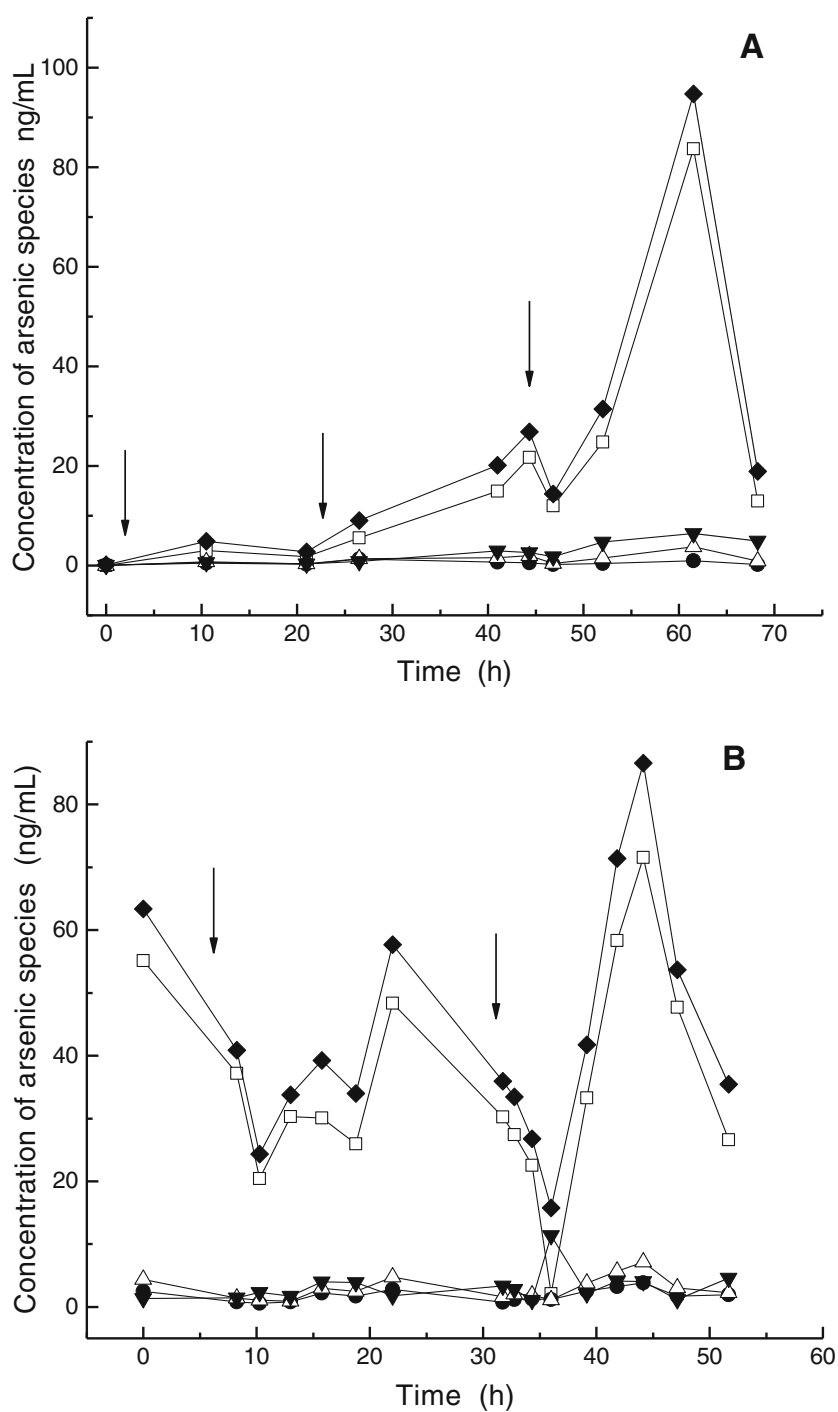

Fig. 5 Temporal profiles showing the concentrations of arsenic species in the saliva of APL patients. The patients received an intravenous infusion of a $10 \mathrm{mg}$ dose of arsenic trioxide daily. The arrows indicate the time at which the infusion started. Collection of saliva samples from patient 4 (a) lasted $72 \mathrm{~h}$ with three arsenic $\left(\mathrm{As}^{\mathrm{III}}\right)$ administrations of long infusion duration (about $18 \mathrm{~h}$ ), and saliva samples from patient 6 (b) were collected for $52 \mathrm{~h}$ with two administrations of short infusion duration (below $4 \mathrm{~h}$ ). Squares $\mathrm{As}^{\mathrm{III}}$, circles $\mathrm{DMA}^{\mathrm{V}}$, upright triangles $\mathrm{MMA}^{\mathrm{V}}$, inverted triangles $\mathrm{As}^{\mathrm{V}}$, diamonds sum of arsenic species

$\mathrm{As}^{\mathrm{III}}$ in the human body. The cytotoxicity and genotoxicity of $\mathrm{MMA}^{\mathrm{III}}$ were shown to be greater than those of inorganic arsenic and pentavalent methylated arsenicals [12, 32-35]

Thiolated methylated arsenicals have recently been identified as arsenic metabolites in human urine and nails [30, 31]. The present study also shows the presence of MMMTA ${ }^{\mathrm{V}}$ in the saliva of APL patients (patients 3, 7, and 8) undergoing arsenic treatment. Little is known about how these thiolated metabolites of arsenic are produced in the human body. Previous studies demonstrated that thiolated arsenicals may be produced in the gastrointestinal tract of rats by intestinal flora
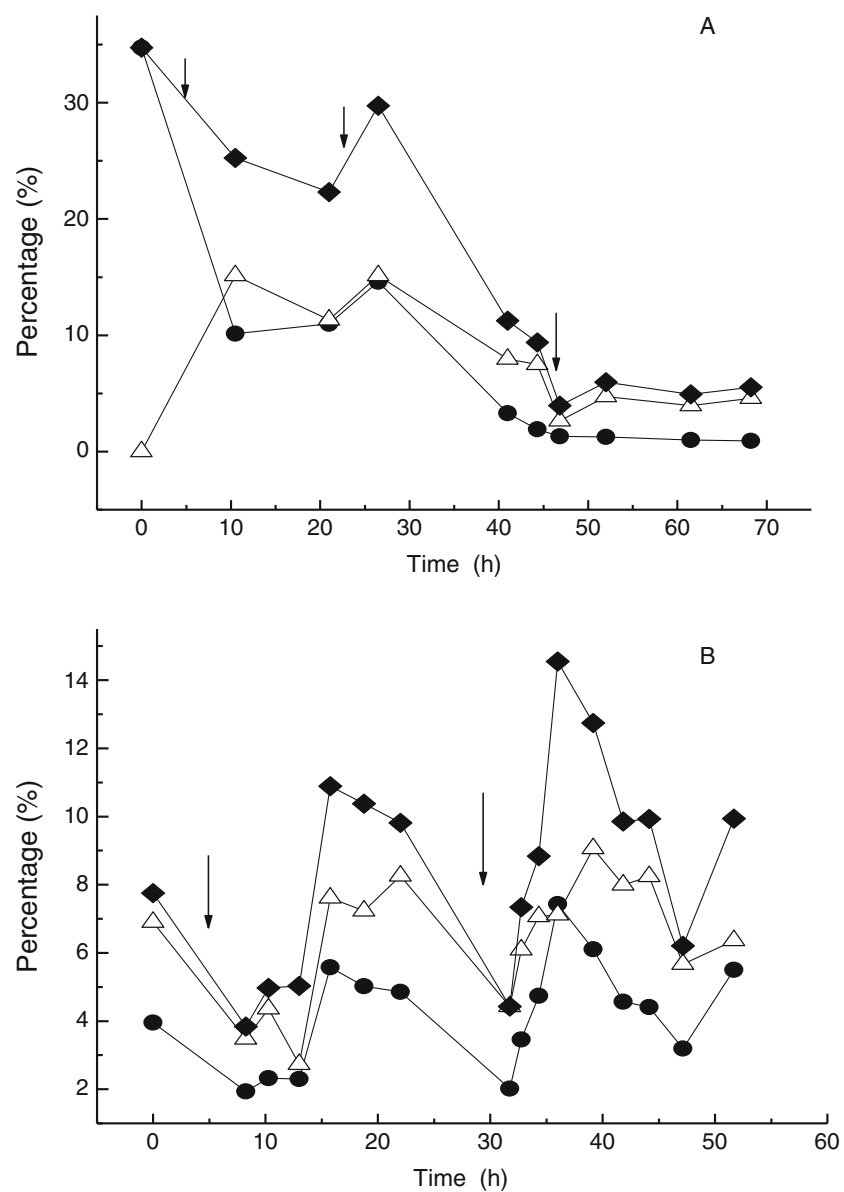

Fig. 6 Temporal profiles showing the percentages of methylated arsenicals in the saliva of APL patient 4 (a) and patient 6 (b). The procedures for arsenic administration were the same as described for Fig. 5. Triangles $\mathrm{MMA}^{\mathrm{V}}$, circles $\mathrm{DMA}^{\mathrm{V}}$, diamonds sum of methylated arsenic

$[46,47]$. However, in our study arsenic was administered to APL patients via intravenous infusion, and it was unlikely that MMMTA $^{\mathrm{V}}$ in the saliva of APL patients was produced in the gastrointestinal tract. Thiolated arsenicals could probably be formed using $\mathrm{H}_{2} \mathrm{~S}$ produced from enzymatically catalyzed reactions in mammalian cells $[48,49]$. Thiolated methylated arsenicals were shown to be more toxic than their oxygencontaining analogs and exhibited toxicity comparable to that of trivalent arsenicals [30, 36-38].

Most arsenic infused is excreted from the bodies of APL patients through urine $[15,50]$. The temporal profiles of salivary arsenicals depicted in our present study might well indicate the overall process of arsenic infusion, metabolism, and tributary excretion from the body. Arsenic accumulated in the saliva of patient 4 in the initial stage of treatment, but in the saliva of patient 6 the arsenic concentration reached a steady state after the adaptation to arsenic treatment. Likewise, a steady state was also reached in the urine within 5 days after repeated ingestion of 125$1,000 \mu \mathrm{g} \mathrm{As}{ }^{\mathrm{III}}$ daily [50]. 
Many efforts have been made to understand whether high doses of ingested $\mathrm{As}^{\mathrm{III}}$ can affect methylation of arsenic in the living body. It was demonstrated that the formation of $\mathrm{DMA}^{\mathrm{V}}$ could be effectively inhibited by heavy ingestion of $\mathrm{As}^{\mathrm{III}}[51$, 52]. Compared with the general population, APL patients who received high doses of $A s^{\text {III }}$ intravenously had a lower fraction of $\mathrm{DMA}^{\mathrm{V}}$ in their urine [15], an observation that was supported by the saliva analysis in the present study. Methylated arsenicals accounted for $24 \%$ of arsenic in the saliva of a general population chronically exposed to arsenic in drinking water [23]. In contrast, the percentage of methylated arsenicals in the saliva of APL patients was only $7.8 \%$. Additionally, the percentage of methylated arsenicals in the saliva of APL patients significantly decreased following each $\mathrm{As}^{\mathrm{III}}$ infusion, reflecting possible saturation of arsenic methylation by the high levels of As ${ }^{\mathrm{III}}$ in the body of APL patients.

Acknowledgments We thank the patients and hospital staff for their participation in this study. This work was supported by the Canadian Institutes of Health Research, the Natural Sciences and Engineering Research Council of Canada, the Canada Research Chairs Program, Alberta Innovates, Alberta Health and Wellness, and the National Natural Science Foundation of China (21077033).

Open Access This article is distributed under the terms of the Creative Commons Attribution License which permits any use, distribution, and reproduction in any medium, provided the original author(s) and the source are credited.

\section{References}

1. Shen ZX, Chen GQ, Ni JH, Li XS, Xiong SM, Qiu QY, Zhu J, Tang W, Sun GL, Yang KQ, Chen Y, Zhou L, Fang ZW, Wang YT, Ma J, Zhang P, Zhang TD, Chen SJ, Chen Z, Wang ZY (1997) Use of arsenic trioxide $\left(\mathrm{As}_{2} \mathrm{O}_{3}\right)$ in the treatment of acute promyelocytic leukemia (APL): II. Clinical efficacy and pharmacokinetics in relapsed patients. Blood 89(9):3354-3360

2. Niu C, Yan H, Yu T, Sun HP, Liu JX, Li XS, Wu W, Zhang FQ, Chen Y, Zhou L, Li JM, Zeng XY, Yang RR, Yuan MM, Ren MY, Gu FY, Cao Q, Gu BW, Su XY, Chen GQ, Xiong SM, Zhang TD, Waxman S, Wang ZY, Chen Z, Hu J, Shen ZX, Chen SJ (1999) Studies on treatment of acute promyelocytic leukemia with arsenic trioxide: remission induction, follow-up, and molecular monitoring in 11 newly diagnosed and 47 relapsed acute promyelocytic leukemia patients. Blood 94(10):3315-3324

3. Zhu J, Chen Z, Lallemand-Breitenbach V, de The H (2002) How acute promyelocytic leukaemia revived arsenic. Nat Rev Cancer 2 (9):705-713

4. Mathews V, George B, Lakshmi KM, Viswabandya A, Bajel A, Balasubramanian P, Shaji RV, Srivastava VM, Srivastava A, Chandy M (2006) Single-agent arsenic trioxide in the treatment of newly diagnosed acute promyelocytic leukemia: durable remissions with minimal toxicity. Blood 107(7):2627-2632

5. Quezada G, Kopp L, Estey E, Wells RJ (2008) All-trans-retinoic acid and arsenic trioxide as initial therapy for acute promyelocytic leukemia. Pediatr Blood Cancer 51(1):133-135

6. Leu L, Mohassel L (2009) Arsenic trioxide as first-line treatment for acute promyelocytic leukemia. Am J Health Syst Pharm 66 (21):1913-1918
7. Wang H, Hao L, Wang X, Li J, Wu Q, Bian S (2010) Retrospective study of arsenic trioxide for childhood acute promyelocytic leukemia in China: a single-center experience. Int J Hematol 91(5):820-825

8. Westervelt P, Brown RA, Adkins DR, Khoury H, Curtin P, Hurd D, Luger SM, Ma MK, Ley TJ, DiPersio JF (2001) Sudden death among patients with acute promyelocytic leukemia treated with arsenic trioxide. Blood 98(2):266-271

9. Cashin R, Burry L, Peckham K, Reynolds S, Seki JT (2008) Acute renal failure, gastrointestinal bleeding, and cardiac arrhythmia after administration of arsenic trioxide for acute promyelocytic leukemia. Am J Health Syst Pharm 65(10):941-946

10. Chen GQ, Shi XG, Tang W, Xiong SM, Zhu J, Cai X, Han ZG, Ni JH, Shi GY, Jia PM, Liu MM, He KL, Niu C, Ma J, Zhang P, Zhang TD, Paul P, Naoe T, Kitamura K, Miller W, Waxman S, Wang ZY, de The H, Chen SJ, Chen Z (1997) Use of arsenic trioxide $\left(\mathrm{As}_{2} \mathrm{O}_{3}\right)$ in the treatment of acute promyelocytic leukemia (APL): $\mathrm{I}$. $\mathrm{As}_{2} \mathrm{O}_{3}$ exerts dose-dependent dual effects on APL cells. Blood 89(9):3345-3353

11. Zhu Q, Zhang JW, Zhu HQ, Shen YL, Flexor M, Jia PM, Yu Y, Cai X, Waxman S, Lanotte M, Chen SJ, Chen Z, Tong JH (2002) Synergic effects of arsenic trioxide and cAMP during acute promyelocytic leukemia cell maturation subtends a novel signaling cross-talk. Blood 99(3):1014-1022

12. Chen GQ, Zhou L, Styblo M, Walton F, Jing Y, Weinberg R, Chen Z, Waxman S (2003) Methylated metabolites of arsenic trioxide are more potent than arsenic trioxide as apoptotic but not differentiation inducers in leukemia and lymphoma cells. Cancer Res 63(8):1853-1859

13. Li L, Wang J, Ye RD, Shi G, Jin H, Tang X, Yi J (2008) PML/ RAR $\alpha$ fusion protein mediates the unique sensitivity to arsenic cytotoxicity in acute promyelocytic leukemia cells: mechanisms involve the impairment of cAMP signaling and the aberrant regulation of NADPH oxidase. J Cell Physiol 217(2):486-493

14. Zhang XW, Yan XJ, Zhou ZR, Yang FF, Wu ZY, Sun HB, Liang WX, Song AX, Lallemand-Breitenbach V, Jeanne M, Zhang QY, Yang HY, Huang QH, Zhou GB, Tong JH, Zhang Y, Wu JH, Hu HY, de The H, Chen SJ, Chen Z (2010) Arsenic trioxide controls the fate of the PML-RAR $\alpha$ oncoprotein by directly binding PML. Science 328(5975):240-243

15. Wang Z, Zhou J, Lu X, Gong Z, Le XC (2004) Arsenic speciation in urine from acute promyelocytic leukemia patients undergoing arsenic trioxide treatment. Chem Res Toxicol 17(1):95-103

16. Fukai Y, Hirata M, Ueno M, Ichikawa N, Kobayashi H, Saitoh H, Sakurai T, Kinoshita K, Kaise T, Ohta S (2006) Clinical pharmacokinetic study of arsenic trioxide in an acute promyelocytic leukemia (APL) patient: speciation of arsenic metabolites in serum and urine. Biol Pharm Bull 29(5):1022-1027

17. Yoshino Y, Yuan B, Miyashita S, Iriyama N, Horikoshi A, Shikino O, Toyoda H, Kaise T (2009) Speciation of arsenic trioxide metabolites in blood cells and plasma of a patient with acute promyelocytic leukemia. Anal Bioanal Chem 393(2):689-697

18. Thomas DJ, Waters SB, Styblo M (2004) Elucidating the pathway for arsenic methylation. Toxicol Appl Pharmacol 198(3):319-326

19. Bentley R, Chasteen TG (2002) Microbial methylation of metalloids: arsenic, antimony, and bismuth. Microbiol Mol Biol Rev 66 (2):250-271

20. Cullen WR, Reimer KJ (1989) Arsenic speciation in the environment. Chem Rev 89:713-764

21. Le XC (2001) Arsenic speciation in the environment and humans. In: Frankenberger WT Jr (ed) Environmental chemistry of arsenic. Dekker, New York, pp 95-116

22. Sun G, Xu Y, Li X, Jin Y, Li B, Sun X (2007) Urinary arsenic metabolites in children and adults exposed to arsenic in drinking water in Inner Mongolia, China. Environ Health Perspect 115(4):648-652

23. Yuan C, Lu X, Oro N, Wang Z, Xia Y, Wade TJ, Mumford J, Le XC (2008) Arsenic speciation analysis in human saliva. Clin Chem 54(1):163-171 
24. Lew K, Yuan CG, Acker JP, Le XC (2008) Salivary arsenic as a biomarker for arsenic exposure. Cell Biol Toxicol 24:367-371

25. Lew K, Acker JP, Gabos S, Le XC (2010) Biomonitoring of arsenic in urine and saliva of children playing on playgrounds constructed from chromated copper arsenate-treated wood. Environ Sci Technol 44(10):3986-3991

26. Hall M, Chen Y, Ahsan H, Slavkovich V, van Geen A, Parvez F, Graziano J (2006) Blood arsenic as a biomarker of arsenic exposure: results from a prospective study. Toxicology 225(2-3):225233

27. Le XC, Lu X, Ma M, Cullen WR, Aposhian HV, Zheng B (2000) Speciation of key arsenic metabolic intermediates in human urine. Anal Chem 72(21):5172-5177

28. Le XC, Ma M, Cullen WR, Aposhian HV, Lu X, Zheng B (2000) Determination of monomethylarsonous acid, a key arsenic methylation intermediate, in human urine. Environ Health Perspect 108 (11):1015-1018

29. Del Razo LM, Styblo M, Cullen WR, Thomas DJ (2001) Determination of trivalent methylated arsenicals in biological matrices. Toxicol Appl Pharmacol 174(3):282-293

30. Raml R, Rumpler A, Goessler W, Vahter M, Li L, Ochi T, Francesconi KA (2007) Thio-dimethylarsinate is a common metabolite in urine samples from arsenic-exposed women in Bangladesh. Toxicol Appl Pharmacol 222(3):374-380

31. Mandal BK, Suzuki KT, Anzai K, Yamaguchi K, Sei Y (2008) A SEC-HPLC-ICP MS hyphenated technique for identification of sulfur-containing arsenic metabolites in biological samples. J Chromatogr B Anal Technol Biomed Life Sci 874(1-2):64-76

32. Petrick JS, Ayala-Fierro F, Cullen WR, Carter DE, Vasken Aposhian $\mathrm{H}$ (2000) Monomethylarsonous acid (MMA(III)) is more toxic than arsenite in Chang human hepatocytes. Toxicol Appl Pharmacol 163 (2):203-207

33. Mass MJ, Tennant A, Roop BC, Cullen WR, Styblo M, Thomas DJ, Kligerman AD (2001) Methylated trivalent arsenic species are genotoxic. Chem Res Toxicol 14(4):355-361

34. Styblo M, Del Razo LM, Vega L, Germolec DR, LeCluyse EL, Hamilton GA, Reed W, Wang C, Cullen WR, Thomas DJ (2000) Comparative toxicity of trivalent and pentavalent inorganic and methylated arsenicals in rat and human cells. Arch Toxicol 74 (6):289-299

35. Charoensuk V, Gati WP, Weinfeld M, Le XC (2009) Differential cytotoxic effects of arsenic compounds in human acute promyelocytic leukemia cells. Toxicol Appl Pharmacol 239(1):64-70

36. Naranmandura H, Ogra Y, Iwata K, Lee J, Suzuki KT, Weinfeld M, Le XC (2009) Evidence for toxicity differences between inorganic arsenite and thioarsenicals in human bladder cancer cells. Toxicol Appl Pharmacol 238(2):133-140

37. Suzuki S, Arnold LL, Pennington KL, Chen B, Naranmandura H, Le XC, Cohen SM (2010) Dietary administration of sodium arsenite to rats: relations between dose and urinary concentrations of methylated and thio-metabolites and effects on the rat urinary bladder epithelium. Toxicol Appl Pharmacol 244(2):99-105

38. Naranmandura H, Bu N, Suzuki KT, Lou Y, Ogra Y (2010) Distribution and speciation of arsenic after intravenous administration of monomethylmonothioarsonic acid in rats. Chemosphere 81(2):206-213

39. Cullen WR, McBride BC, Manji H, Pickett AW, Reglinski J (1989) The metabolism of methylarsine oxide and sulfide. Appl Organometal Chem 3:71-78

40. Naranmandura H, Suzuki N, Iwata K, Hirano S, Suzuki KT (2007) Arsenic metabolism and thioarsenicals in hamsters and rats. Chem Res Toxicol 20(4):616-624

41. Challenger F (1945) Biological methylation. Chem Rev 36:315-361

42. Nigg HN, Stamper JH, Malory LL (1993) Quantification of human exposure to ethion using saliva. Chemosphere 26:897-906

43. Rafael G, Pascale B, Zul V, Paul H, Gideon K (1997) Is saliva suitable for therapeutic monitoring of anticonvulsants in children: an evaluation in the routine clinical setting. Ther Drug Monit 19:637-642

44. Denovan LA, Lu C, Hines CJ, Fenske RA (2000) Saliva biomonitoring of atrazine exposure among herbicide applicators. Int Arch Occup Environ Health 73(7):457-462

45. Barbosa F Jr, Tanus-Santos JE, Gerlach RF, Parsons PJ (2005) A critical review of biomarkers used for monitoring human exposure to lead: advantages, limitations, and future needs. Environ Health Perspect 113(12):1669-1674

46. Kuroda K, Yoshida K, Yoshimura M, Endo Y, Wanibuchi H, Fukushima S, Endo G (2004) Microbial metabolite of dimethylarsinic acid is highly toxic and genotoxic. Toxicol Appl Pharmacol 198(3):345-353

47. Yoshida K, Kuroda K, Zhou X, Inoue Y, Date Y, Wanibuchi H, Fukushima S, Endo G (2003) Urinary sulfur-containing metabolite produced by intestinal bacteria following oral administration of dimethylarsinic acid to rats. Chem Res Toxicol 16(9):1124-1129

48. Kamoun P (2004) Endogenous production of hydrogen sulfide in mammals. Amino Acids 26(3):243-254

49. Suzuki KT, Iwata K, Naranmandura H, Suzuki N (2007) Metabolic differences between two dimethylthioarsenicals in rats. Toxicol Appl Pharmacol 218(2):166-173

50. Buchet JP, Lauwerys R, Roels H (1981) Urinary excretion of inorganic arsenic and its metabolites after repeated ingestion of sodium metaarsenite by volunteers. Int Arch Occup Environ Health 48(2):111-118

51. Styblo M, Delnomdedieu M, Thomas DJ (1996) Mono- and dimethylation of arsenic in rat liver cytosol in vitro. Chem Biol Interact 99(1-3):147-164

52. Li J, Waters SB, Drobna Z, Devesa V, Styblo M, Thomas DJ (2005) Arsenic (+3 oxidation state) methyltransferase and the inorganic arsenic methylation phenotype. Toxicol Appl Pharmacol 204(2):164-169 